\title{
THE ROLE OF GENDER IN THE EVALUATION OF MANAGEMENT EDUCATION AND ITS DEVELOPMENT AT BUSINESS UNIVERSITY IN THE CZECH REPUBLIC
}

\author{
[Role pohlaví v hodnocení výuky manažerských předmětů a jeho vývoj na \\ ekonomické vysoké škole v České republice]
}

\author{
Lucie Vnoučková ${ }^{1}$, Hana Urbancová ${ }^{2}$, Helena Smolová ${ }^{3}$ \\ ${ }^{1}$ University of Economics and Management, Nárožni 2600/9a, 15800 Prague \\ Email: lucie.vnouckova@vsem.cz \\ ${ }^{2}$ Institute of Agricultural Economics and Information, Mánesova 1453/75, 12000 Prague \\ Email: urbancova.hana@uzei.cz \\ ${ }^{3}$ Czech Academy of Agricultural Sciences, Slezská 7/100, 12000 Prague \\ Email:cazv@cazv.cz
}

\begin{abstract}
This paper examines the impact of students' gender on management education evaluation. The paper aims to test and identify the influence of gender in higher education on selected factors impacting evaluation of management education by university students and to evaluate its development. The areas of influence have been analysed using characteristics of evaluation of management lessons, teachers and subjects. Data for this primary research was gathered using a questionnaire survey administered to business university students in the period between 2015 to 2018. Results show that the number of higher educated women is increasing and their evaluation of management subjects, teachers and lessons is different compared to men. Specific factors impacting evaluation of management education and their development are further tested and discussed. The results may be used in practice to identify current approaches towards higher education by students' gender preferences. Limitation of the findings of this study is that its application may be impacted because the sample size was limited to business university students. It may be taken as a case study and a base for further research and benchmarking between universities.
\end{abstract}

Keywords: business university, gender, management education, quality, student.

JEL classification: A23, D83, M53

Received: 2.11.2018; Reviewed: 16.11.2018; 3.12.2018; Accepted: 19.6.2019

\section{Introduction}

With the increasing importance of higher education for national development, there is also a growing public concern about the effectiveness of this education. Higher education represents an efficient and effective method of human capital accumulation and the development of science and new technologies (Alauddin, Kifle 2014; Markley 2004; Claar, Dias and Shields 2014). Quality in higher education is a multi-criteria and multidimensional concept; therefore quality assurance systems have to be appropriate according to the subject being evaluated. Evaluation and measuring the quality in higher education institution are very difficult, because of their intangible, variable, inseparable parts. Therefore, universities should have a systematic process quality evaluation in place as an integral component of the faculty and a professional review process (Al-Busaidi, Aldhafri and Büyükyavuz (2016); Benton, Cashin 2014). The quality evaluation process should extend beyond student evaluations and include expectations for continuous improvement (Ojode 2000; Driscoll and Hunt 2015). This study adds another dimension to the evaluation process with the introduction of perspectives based on gender. 
This paper aims to test and identify the influence of the role of gender in higher education on selected factors impacting evaluation of management education by university students and to evaluate its development. The theoretical framework of this study consists of a literature review based on an analysis of scientific papers and publications dealing with the area of student retention and strategies, policies and applicable approaches to it. The primary research was conducted involving analysis of documents and databases related to the organisation of student support, student feedback and evaluation of study, lessons, courses and teachers of an analysed business university in the period starting from 2015 .

The structure of the article is following: the first chapter Theoretical Background focuses on summarizing of the current knowledge base in the area of higher education, Materials and Methods includes the detailed description of the theoretical knowledge and research methods, by application of which the primary data was collected; the results obtained and their interpretation are included in the chapter Results, and Discussion and the summary is included in the chapter Conclusion.

\section{Theoretical background}

Student evaluation of studies is commonly and very often limited to lectures, education, teacher and subject quality as major indicators (Benton \& Cashin 2014; Laube et al. (2007). Major decisions regarding a future orientation of a higher education institution and a long line of other decisions such as promotion, remuneration, etc., are based on these evaluations. According to Markley (2004) teachers are the foundations of a learning process. Furthermore, it was proven that teachers' evaluation has a positive impact on teachers who perceive this feedback mostly in a positive way and try to improve their approach toward the education process and interaction with students, upgrade content of their lessons and also their teaching methods (Flodén 2017). Based on results of the study by Al-Busaidi, Aldhafri and Büyükyavuz (2016) the valued university teacher should have such skills as respect towards students, recognition of students' identity, ability to listen to them and a will to help them.

Moreover, university teacher should treat all students equally, should not make any differences between them and should help to build their self-confidence. Additionally, it is necessary that teachers are adequately equipped for the teaching lecture and his/her interpretation of the course should be understandable and clear. On the other hand, one can still find higher education institutions or universities that do not use nor value students' evaluation of teaching or open to use it (Feldman 2007; Hilali et al. 2015). If we look into the typical areas and characteristics which can be evaluated by students, Cashin (1995) has set six main areas: course organisation and planning, clarity and communication skills, teacher and student interaction/rapport, course difficulty/workload, grading and examinations and last but not least student self-rated learning. Similar attributes are used for evaluation and analysis of student assessment in this paper (those are subject, lesson and teacher) according to Handal, Wood and Muchatuta (2011) or Chui et al. (2016); Sulong (2014).

Evaluation of the educational effectiveness is impacted by many factors as documented by Berk (2005) or Etuk et al. (2013). They stated that basic students' characteristics such as attitude, ability, motivation, gender, age, maturation and institutions' characteristics such as class size, classroom facilities, available technology, learning resources, school climate could have an influence on students' performance regardless of instructor's actions.

Research regarding students' gender has not provided unified results. For example, Chamberlin and Hickey (2001) confirmed with their research that students' gender 
significantly affects an evaluation of education and its elements. Additionally, Kohn and Hatfield (2006) and Walumbwa and Ojode (2000) discovered within their studies that female students, in general, evaluate education efficiency and teacher quality significantly better than males. Furthermore, women tend to care about the evaluation process much more than male students (Heine, Maddox 2009), while female's evaluation is usually more precise and more efficient (Darby 2006). Stoet and Geary (2014) in their study provided a rationale for this difference who stated based on their study that females are more committed to their studies and therefore they put a great emphasis on teachers' effectiveness. However, this is inconsistent with the results of Koushki and Kuhn (1982). On the other hand, according to Liu (2011), whose work focused on distance learning students, the gender of students does not affect the evaluation of education at all. Colbeck, Cabrera and Terenzini (2000) in their work focused on the evaluation of interactions between students and teachers and subsequently increased motivation towards classes' attendance, a rise of trust or own skills and abilities may be considered equivalent to male and female students. As different modern technologies tend to take over the university teaching process, it is crucial to mention results of research by Claar, Dias and Shields (2014), who revealed that gender does not have any statistically significant relation to the acceptation of evaluation of the use of modern technologies.

This paper focuses on the role of gender and its effect on students' evaluation of their studies. It is, therefore, necessary to consider that this attribute may also affect a relationship with a teacher; that is whether the teacher is a male or a female in the studied case. This interaction was confirmed by the study of Arbuckle and Williams (2003) and Aleamoni (1999). Several studies have also shown that students have a tendency to evaluate in a more favourable way teacher of the same gender as the student (Centra, Gaubatz 2000). Boring, Ottoboni and Stark (2016) added that most female teachers are discriminated during evaluations although their performance is, in fact, the same as their male colleagues. This overall preference of teachers was also confirmed by many studies (MacNell, Driscoll and Hunt 2015; Basow and Silberg 1987; Zare-ee, Don and Tohidian 2016). The last-mentioned authors found out that students males evaluated teachers - males significantly better than students - females. Female students overall evaluated teachers - males better than females, but this difference is not significant. To support these statements, it is possible to mention the study by Cramer and Alexitch (2000), who states that the study program, respectively the course taught, and students' gender are closely connected with evaluation of the teacher, subject and lesson.

\section{Methods}

This paper is a case study of one private business university. The university is only focused on business, economics and management and is not further split into faculties. This article focuses on the evaluation of all subjects, teachers and courses taught in the years 2015 to 2018. All subjects taught at the university were evaluated in the searched period.

Moreover, all students who participated in the education process had to take part the surveying compulsory. The total number of students per each academic year is higher than the number of students who participated in the survey, but the remaining students are in the prolongation of studies or have free semester for writing their final thesis. Therefore the results are representative for the searched case university. This paper shows a comparison of approaches of men and women towards education; it's perceived quality and their study and professional aims. In every questionnaire, each student had to indicate his or her gender. Therefore it was easy to evaluate the questionnaires separately from men and women. 
The research was prepared using both a qualitative and quantitative method of analysis of secondary and primary resources, knowledge synthesis, induction, deduction and comparison. As part of secondary resources, scientific articles dealing with the theme were analysed. The primary data was gathered using quantitative research, through data collection using questionnaires. The questionnaire was administered to students, bachelors and masters, of the studied business university in the period starting from 2015 and ending in 2018. The total number of the students was on average 1958 in this period.

The second part of this paper analyses and evaluates the results of the primary survey data. The student dataset comprised in total 5,481 surveys (the sample file of the respondents). The evaluated subjects were in disciplines which include Management, Economics, Business, Human Resources, Marketing and Law. Only students who passed the whole education and evaluation process of mentioned selected modules were part of the survey.

The respondents demographic profile is as follows $36.6 \%$ men, $63.4 \%$ women; $46.5 \%$ work in the area of study, $52.0 \%$ do not work, approximately $4 \%$ did not indicate employment status; $53.2 \%$ plan to work in the area of studied subjects, $15.6 \%$ do not plan to work in the area of studied subjects, and the rest does not know yet. Over the studied period, the percentage of men fluctuated between $34.0 \%$ and $40.1 \%$ and the percentage of women were from $59.2 \%$ to $66 \%$.

The number of students and their division into men and women is shown in Table 1.

Table 1: Number of students according to gender among the studied period

\begin{tabular}{|l|c|c|c|c|}
\hline Year & Total No of students & Questioned students & Men & Women \\
\hline $2015 / 16$ & 2393 & 2256 & 841 & 1415 \\
\hline $2016 / 17$ & 2188 & 1764 & 677 & 1087 \\
\hline $2017 / 18$ & 1958 & $1103^{*}$ & $409^{*}$ & $694^{*}$ \\
\hline
\end{tabular}

* only first trimester

Source: own survey

The data collection instrument included questions to measure the quality of education at the studied university. The questions were designed based on theories (see theoretical background) and similar researches. The questionnaire addressed three main areas, which includes lessons and their content, the course/subject and its structure and usefulness, and the teacher's quality. Other than the quality of education, the questionnaires also measured study materials, texts and presentations, the teacher's personality and abilities, the technology used in the educational process, connection with practice, technical and organisational facilities and equipment.

Respondents' reactions to questions related to subjects, courses and teachers were measured. Attitudes to the given matter were restricted by offering a set of several statements. The extremes of the five-point scale represented bipolar concepts of the evaluation dimension. All the questions were measured in a Likert type scale with verbal anchors in 1 (strongly disagree) and 5 (strongly agree) or, provided it was not possible to favour either of the sides, neutral value (the median value was characterised by number 3 ). The scale permitted not only the specification of respondents' attitudes but also their intensity.

All the primary data were evaluated using descriptive statistics. In addition, the dependence among qualitative characteristics was tested to assess the relationships between searched 
attributes, to verify the data obtained and its further analysis (Hendl 2006). The tools of twodimensional statistics were employed using Pearson's Chi-square test (see below):

$X^{2}=\sum_{i=1}^{n} \frac{\left(O_{i}-E_{i}\right)^{2}}{E_{i}}$

Description:

$\chi 2=$ Pearson's cumulative test statistic, which asymptotically approaches a $\chi^{2}$ distribution;

$\mathrm{Oi}=$ the number of observations of type $\mathrm{i}$;

$\mathrm{Ei}=\mathrm{Npi}=$ the expected (theoretical) frequency of type $\mathrm{i}$, asserted by the null hypothesis that the fraction of type $\mathrm{i}$ in the population is $\mathrm{pi}$;

$\mathrm{n}=$ total number of observations.

To evaluate the results Microsoft Excel and IBM SPSS statistics were used.

A case study was used as a qualitative method which allowed a detailed study of one case to apply the acquired findings to understand similar cases. Case study research refers to an indepth, detailed study of an individual or a small group of individuals, in this case in one business university $(n=5,481$ respondents). Such studies are typically qualitative, resulting in a narrative description of behaviour or experience. It must be stated that case study research is not used to determine cause and effect, nor it is used to discover generalizable truths or make predictions, rather, the emphasis in case study research is placed on exploration and description of a phenomenon.

\section{Results}

Based on the results, the total number of higher educated women is increasing. Statistically significant differences were found amongst gender. Women statistically significantly more often study and visit courses in the area of business management $(\mathrm{p}=0.000)$.

The results show that students evaluate positively subjects (on the scale where one is the best and five is the worst), lectures and also teachers. The subjects studied in the area mostly filled the expectations (average value 1.75 by males; 1.73 by females). Even better results were given when evaluating lessons (average value 1.44 by males; 1.46 by females) and teachers (average value 1.42 by males and also by females). It is possible to observe that the average evaluation of all three areas is getting better during the studied period (from 2015 till now). The evaluation and the given feedback have the positive influence on teachers, their approach towards students, upgrade of study materials and preparation of lessons and courses (see Table 2).

Table 2: Gender differences in perceived quality of education

\begin{tabular}{|l|c|c|c|c|c|c|}
\hline \multirow{2}{*}{ Trimester } & \multicolumn{2}{|c|}{ Subject } & \multicolumn{2}{c|}{ Lesson } & \multicolumn{2}{c|}{ Teacher } \\
\cline { 2 - 7 } & $\mathrm{M}$ & $\mathrm{F}$ & $\mathrm{M}$ & $\mathrm{F}$ & $\mathrm{M}$ & $\mathrm{F}$ \\
\hline 1st trimester 2015/16 & 1.93 & 1.87 & 1.60 & 1.61 & 1.62 & 1.59 \\
\hline 2nd trimester 2015/16 & 1.80 & 1.80 & 1.47 & 1.52 & 1.47 & 1.53 \\
\hline 3rd trimester 2015/16 & 1.70 & 1.69 & 1.44 & 1.44 & 1.42 & 1.41 \\
\hline 1st trimester 2016/17 & 1.80 & 1.79 & 1.44 & 1.50 & 1.44 & 1.44 \\
\hline 2nd trimester 2016/17 & 1.74 & 1.65 & 1.44 & 1.43 & 1.39 & 1.37 \\
\hline 3rd trimester 2016/17 & 1.64 & 1.63 & 1.32 & 1.35 & 1.28 & 1.31 \\
\hline 1st trimester 2017/18 & 1.67 & 1.65 & 1.38 & 1.37 & 1.33 & 1.32 \\
\hline Average & 1.75 & 1.73 & 1.44 & 1.46 & 1.42 & 1.42 \\
\hline
\end{tabular}

Note: $\mathrm{M}=$ male, $\mathrm{F}=$ female; scale 1 to 5 , where 1 is the best

Source: own survey 
When evaluating differences between gender and evaluation of education quality, no statistically significant differences were found in students' gender and their perception related to the level of subjects, lessons/courses and teachers quality. Both males and females evaluate all areas without statistically significant differences. On the other hand, the evaluation by females is slightly better in the area of subject evaluation. On the contrary, lessons/courses are evaluated better by males. It is possible to summarise that females are more focused on content than the course. Evaluation of teachers is almost equal by males and female as evidenced by Table 2 .

Additionally, the differences amongst work experiences of attending students were tested. Statistically significant differences were found between males and females in the area of work in the studied program and plans for the future job (Table 3).

Table 3: Gender differences in work during studies

\begin{tabular}{|l|c|c|c|c|}
\hline \multirow{2}{*}{ Trimester } & Work in the area of study (\%) & \multicolumn{2}{c|}{ Plan to work in the area of study (\%) } \\
\cline { 2 - 4 } & Male & Female & Male & Female \\
\hline 1st trimester 2015/16 & 46.552 & 53.448 & 43.704 & 56.296 \\
\hline 2nd trimester 2015/16 & 42.289 & 57.711 & 37.199 & 62.801 \\
\hline 3rd trimester 2015/16 & 37.500 & 62.500 & 33.046 & 66.954 \\
\hline 1st trimester 2016/17 & 40.052 & 59.948 & 36.471 & 63.529 \\
\hline 2nd trimester 2016/17 & 38.000 & 62.000 & 36.591 & 63.409 \\
\hline 3rd trimester 2016/17 & 38.710 & 61.290 & 37.586 & 62.414 \\
\hline 1st trimester 2017/18 & 39.842 & 60.158 & 39.049 & 60.951 \\
\hline Average & 40.421 & 59.579 & 37.664 & 62.336 \\
\hline
\end{tabular}

Source: own survey

Statistically significant differences were found within gender of students who work or plan to work in the area of their studied program $(\mathrm{p}=0.000)$. Women statistically significantly more often work and plan to work in the area of their study program.

Moreover, the differences between the perception of male and female teachers by attendant students were tested. No statistically significant differences were found between the perception of males and females in all searched areas listed in Table 4. The studied areas were perception of a male/female teacher as an expert, his/her ability to motivate students to learn, his/her ability to create positive atmosphere in classroom, his/her ability to connect theory and practice and his/her ability to discuss with students and giving them opportunity to express their opinion.

Table 4: Gender differences in teachers' perception

\begin{tabular}{|l|c|c|c|c|c|c|c|c|c|c|}
\hline $\begin{array}{l}\text { Evaluation } \\
\text { of teacher }\end{array}$ & \multicolumn{2}{|c|}{ he/she is expert } & \multicolumn{2}{|c|}{$\begin{array}{l}\text { motivates to } \\
\text { learn }\end{array}$} & \multicolumn{2}{c|}{$\begin{array}{l}\text { creates a } \\
\text { positive } \\
\text { atmosphere }\end{array}$} & \multicolumn{2}{c|}{$\begin{array}{l}\text { connects theory } \\
\text { and practice }\end{array}$} & \multicolumn{2}{c|}{$\begin{array}{c}\text { opportunity to } \\
\text { express an } \\
\text { opinion }\end{array}$} \\
\hline $\begin{array}{l}\text { Gender of } \\
\text { teacher }\end{array}$ & $\mathrm{M}$ & $\mathrm{F}$ & $\mathrm{M}$ & $\mathrm{F}$ & $\mathrm{M}$ & $\mathrm{F}$ & $\mathrm{M}$ & $\mathrm{F}$ & $\mathrm{M}$ & $\mathrm{F}$ \\
\hline 1st 2015/16 & 1.30 & 1.40 & 1.93 & 1.73 & 1.50 & 1.36 & 1.71 & 1.78 & 1.38 & 1.34 \\
\hline 2nd 2015/16 & 1.27 & 1.35 & 1.84 & 1.65 & 1.46 & 1.28 & 1.49 & 1.52 & 1.32 & 1.20 \\
\hline 3rd 2015/16 & 1.21 & 1.29 & 1.68 & 1.50 & 1.32 & 1.29 & 1.42 & 1.39 & 1.29 & 1.18 \\
\hline 1st 2016/17 & 1.20 & 1.23 & 1.73 & 1.66 & 1.28 & 1.31 & 1.42 & 1.56 & 1.26 & 1.26 \\
\hline 2nd 2016/17 & 1.17 & 1.20 & 1.66 & 1.54 & 1.31 & 1.98 & 1.40 & 1.41 & 1.28 & 1.17 \\
\hline 3rd 2016/17 & 1.11 & 1.21 & 1.50 & 1.34 & 1.17 & 1.97 & 1.31 & 1.30 & 1.19 & 1.14 \\
\hline 1st 2017/18 & 1.16 & 1.22 & 1.50 & 1.48 & 1.19 & 1.23 & 1.29 & 1.40 & 1.18 & 1.16 \\
\hline Average & 1.20 & 1.27 & 1.69 & 1.56 & 1.32 & 1.49 & 1.43 & 1.48 & 1.27 & 1.21 \\
\hline
\end{tabular}

Note: $\mathrm{M}=$ male, $\mathrm{F}=$ female; scale 1 to 5 , where 1 is the best

Source: own survey 
Furthermore, Table 4 shows constant upgrading of the average evaluation of teachers, all values in the table are getting closer to 1 over the monitored period from autumn 2015 to the academic year 2017/2018.

To be able to see gender differences between evaluations of the teacher by students according to their gender, another analysis was conducted. The results may be seen in Table 5. Again, no statistically significant differences were found between male and female students' evaluation of teacher in the searched areas (teacher is an expert, has the ability to motivate to learn, has the ability to create positive atmosphere in the classroom, to connect theory and practice and to discuss with students and give them opportunity to express their opinions).

Table 5: Evaluation of teacher by gender of students

\begin{tabular}{|c|c|c|c|c|c|c|c|c|c|c|}
\hline $\begin{array}{l}\text { Evaluation } \\
\text { of teacher }\end{array}$ & \multicolumn{2}{|c|}{ he/she is expert } & \multicolumn{2}{|c|}{$\begin{array}{c}\text { motivates to } \\
\text { learn }\end{array}$} & \multicolumn{2}{|c|}{$\begin{array}{c}\text { creates a } \\
\text { positive } \\
\text { atmosphere }\end{array}$} & \multicolumn{2}{|c|}{$\begin{array}{l}\text { connects theory } \\
\text { and practice }\end{array}$} & \multicolumn{2}{|c|}{$\begin{array}{c}\text { opportunity to } \\
\text { express an } \\
\text { opinion }\end{array}$} \\
\hline $\begin{array}{l}\text { Gender of } \\
\text { teacher }\end{array}$ & $\mathrm{M}$ & $\mathrm{F}$ & $\mathrm{M}$ & $\mathrm{F}$ & M & $\mathrm{F}$ & $\mathrm{M}$ & $\mathrm{F}$ & $\mathrm{M}$ & $\mathrm{F}$ \\
\hline 1 st $2015 / 16$ & 1.36 & 1.35 & 1.86 & 1.84 & 1.44 & 1.44 & 1.78 & 1.74 & 1.39 & 1.36 \\
\hline 2nd $2015 / 16$ & 1.23 & 1.34 & 1.69 & 1.77 & 1.33 & 1.39 & 1.44 & 1.52 & 1.26 & 1.25 \\
\hline 3rd 2015/16 & 1.24 & 1.24 & 1.58 & 1.64 & 1.29 & 1.31 & 1.43 & 1.39 & 1.27 & 1.25 \\
\hline 1st 2016/17 & 1.21 & 1.21 & 1.66 & 1.70 & 1.29 & 1.30 & 1.51 & 1.48 & 1.27 & 1.26 \\
\hline 2nd $2016 / 17$ & 1.17 & 1.18 & 1.65 & 1.56 & 1.25 & 1.25 & 1.45 & 1.38 & 1.25 & 1.21 \\
\hline 3rd 2016/17 & 1.06 & 1.14 & 1.48 & 1.51 & 1.12 & 1.20 & 1.23 & 1.35 & 1.16 & 1.20 \\
\hline 1st 2017/18 & 1.11 & 1.19 & 1.40 & 1.57 & 1.12 & 1.24 & 1.25 & 1.31 & 1.13 & 1.22 \\
\hline Average & 1.20 & 1.24 & 1.62 & 1.66 & 1.26 & 1.30 & 1.44 & 1.45 & 1.25 & 1.25 \\
\hline
\end{tabular}

Note: $\mathrm{M}=$ male, $\mathrm{F}=$ female; scale 1 to 5 , where 1 is the best

Source: own survey

As reported in Tables 4 and 5, most of the attributes are evaluated positively (on the scale where one is the best and five is the worst). All analysed statements are fluctuating around the level 1.2 to 1.4 ; the only difference is the motivation to learn, where higher values are observed (fluctuating around 1.6). This statement has poorer evaluation than other searched statements (the average is 1.59 to 1.69 ). Other average values are in the interval $\langle 1.20 ; 1.49\rangle$. Otherwise, students perceive the teacher as an expert (average fluctuate around 1.2) who discuss with them openly and gives them the opportunity to express their opinions (average approx. 1.25).

Furthermore, it is possible to assess from the results in Table 4 and 5 that the studied area mostly filled the expectations. Students perceive teacher as an expert (average value oscillates around 1.20 to 1.27 ), he/she has the ability to motivate them to learn (average value oscillates around 1.56 to 1.69 ), his/her ability to create positive atmosphere in the classroom (average value oscillates around 1.26 to 1.49 ), his/her ability to connect theory and practice (average value oscillates around 1.43 to 1.48 ), and his/her willingness to discuss with students and gives them opportunity to express their opinions (average value oscillates around 1.21 to 1.27). The favourable evaluation was found in the criterion of teachers' perception as an expert and his/her willingness to discuss with students and give them the opportunity to express their opinions. All the results are valid both for male and female students without any differences. The same result is valid for the perception of both male and female teachers.

As the data was deeply analysed and the students questioned, they prefer a focus on practice, instructors who demonstrate the application of lesson. The connection of lessons with case studies and projects is evaluated as the best within the surveyed students. They also value experts from companies for workshops and seminars. 
The overall results do not show serious weaknesses since results show that students evaluate positively subjects (on the scale where one is the best and five is the worst), lectures and also teachers. The studied area mostly filled the expectations (average value fluctuated from 1.42 to 1.75 by males, and from 1.42 to 1.73 by females). Students evaluated all areas of the teachers' qualities at a very good level of satisfaction. This indicates mostly agreement and conformity of responses and also a good perception of the educational process by the interviewed students.

\section{Discussion}

Consistent with the works of Benton and Cashin (2014) and Laube et al. (2007), this paper presented evaluation of teachers' and lectures quality by students' evaluation; specifically in the areas which reflect attributes used by Handal, Wood and Muchatuta (2011). The searched phenomenon was broadened by connection with searched differences caused by students' and also teachers' gender. According to Berk (2005), Chamberlin and Hickey (2001) gender is one of the characteristics that may significantly affect students' evaluation. The presented results of this study clearly show that there is very little difference between male and females when it relates to the evaluation of instruction.

As stated by Heine, Maddox (2009), Darby (2006), females pay more attention to evaluation and are more concrete in their comments in the evaluation. That may be generally explained by output that females more often plan to work in the area of the studied program and thus are more committed to their studies which are following Stoet and Geary (2014). That is the reason why females are more focused on the results of the course more than the content and style of the course, which was found out this presented paper.

Furthermore, in this study, there were found no significant differences in evaluation based on gender, and it is consistent with the works of Kohn and Hatfield (2006), Walumbwa and Ojode (2000) and Chamberlin and Kickey (2001). Another important finding is that females usually evaluate courses and teachers better than males as supported by Liu (2011), Hameed et al. (2015), whose results declare that gender has no significant difference on students' evaluation.

It is possible to see from the results that evaluation of the subject, lesson and teacher and also other attributes and skills of teacher (see tab. 1 and 3) are getting better in every examined period (trimester), which is in line with Flodén (2017), who states that students' evaluation have positive effect on teachers and their performance.

This study found out that the differences related to the evaluation of education and teacher exist, but mostly there are insignificant. Significant results were found when it comes to the subject and future intention of students studying in the searched area.

\section{Conclusion}

The paper focuses on the perception of the education quality in business and management higher education by students. The results show that the number of higher educated women is increasing and their evaluation of management subjects and lessons is different compared to men. Evaluation of the subject is slightly better by females. On the contrary, lessons/courses are evaluated better by males. Furthermore, statistically significant differences were found within the gender of students who work or plan to work in the area of their studied program $(p=0.000)$. Females significantly more often work and plan to work in the area of their study program. The results show that females are more goal-oriented than men. They focus more 
than males on course content than its style and are more attracted by career opportunities in the studied area.

Another major finding is that students who are working in the field are more careful in their evaluation. Moreover, results show that there are no major significant differences in gender in the evaluation of subjects, lessons and teachers.

The results may be used in practice to identify current approaches towards higher education by students' gender. The limits of the article can be deemed to focus on only one business university, the results are not generalizable for other universities, but the sample is representative for the studied university. It may be taken as the case study and a base for further research and benchmarking between universities in the future.

\section{Acknowledgement}

No funding was used. The searched business university is private and no other public funding was used. The data were analysed only by the authors' interest.

\section{References}

[1] AL-BUSAIDI, S., S. ALDHAFRI and O. BÜYÜKYAVUZ, 2016. Effective university instructors as perceived by Turkish and Omani university students. SAGE Open, 6(3), DOI: $10.1177 / 2158244016662900$.

[2] ALEAMONI, L. M., 1999. Student Rating Myths Versus Research Facts from 1924 to 1998. Journal of Personnel Evaluation in Education, 13(2), 153-166. DOI: 10.1023/A:1008168421283.

[3] ARBUCKLE, J. and B. D. WILLIAMS, 2002. Students' Perceptions of Expressiveness: Age and Gender Effects on Teacher Evaluations. Sex Roles, 49(9-10), 507-516. DOI: 10.1023/A:1025832707002.

[4] ALAUDDIN, M. and T. KIFLE, 2014. Does the student evaluation of teaching instrument really measure instructors' teaching effectiveness? An econometric analysis of students' perceptions in economics courses, Economic Analysis and Policy, 44(2), 156-168.

[5] BASOW, S. A. and N. T. SILBERG, 1987. Student evaluations of college professors: Are female and male professors rated differently? Journal of educational psychology, 79(3), 308-314. DOI: 10.1037/0022-0663.79.3.308.

[6] BENTON, S. L. and W. E. CASHIN, 2014. Student ratings of instruction in college and university courses. In: Paulsen, M. B. (Ed.). Higher education: Handbook of theory and research, 279-326. Dordrecht, The Netherlands: Springer. DOI: doi.org/10.1007/978-94017-8005-6_7.

[7] BERK, R. A., 2005. Survey of 12 Strategies to Measure Teaching Effectiveness. International Journal of Teaching and Learning in Higher Education, 17(1), 48-62.

[8] BORING, A., K. OTTOBONI and P. STARK, 2016. Student evaluations of teaching (mostly) do not measure teaching effectiveness. ScienceOpen Research. DOI: 10.14293/S2199-1006.1.SOR-EDU.AETBZC.v1.

[9] CASHIN, W. E., 1995. Student Ratings of Teaching: The Research Revisited. Idea Paper No. 32. Center for Faculty Evaluation and Development. 
[10] CENTRA, J. A. and N. B. GAUBATZ, 2000. Is There Gender Bias in Student Evaluations of Teaching? Journal of Higher Education, 71(1), 17-33. DOI: 10.1080/00221546.2000.11780814.

[11] CLAAR, C., L. PORTOLESE DIAS and R. SHIELDS, 2014. Student acceptance of learning management systems: A study on demographics. Issues in Information Systems, 15(1), 409-417.

[12] COLBECK, C. L., A. F. CABRERA and P. T. TERENZINI, 2000. Learning Professional Confidence: Linking Teaching Practices, Students Self-Perceptions, and Gender. The Review of Higher Education, 24(2), 173-191. DOI: 10.1353/rhe.2000.0028.

[13] CRAMER, K. M. and L. R. ALEXITCH, 2000. Student Evaluations of College Professors: Identifying Sources of Bias. Canadian Journal of Higher Education, 30(2), 143-64.

[14] DARBY, J. A., 2006. The effects of the elective or required status of courses on student evaluations. Journal of Vocational Education and Training, 58(1), 19-29. DOI: 10.1080/13636820500507708.

[15] ETUK, E. N., M. E. AFANGIDEH and A. O. UYA, 2013. Students' Perception of Teachers' Characteristics and Their Attitude towards Mathematics in Oron Education Zone, Nigeria, International Education Studies, 6(2), 197-204.

[16] FELDMAN, K. A., 2007. Identifying exemplary teachers and teaching: Evidence from student ratings. In: Perry, R. P., \& Smart, J. C. The scholarship of teaching and learning in higher education: An evidence-based perspective. Dordrecht: Springer. DOI: 10.1002/t1.37219966509.

[17] FLODÉN, J., 2017. The impact of student feedback on teaching in higher education. Assessment \& Evaluation in Higher Education, 42(7), 1054-1068. DOI: 10.1080/02602938.2016.1224997.

[18] HAMEED, F., A. ALI, A. HAMEED, Z. SALEEM and Y. JAVED, 2015. Teacher evaluation: The role of gender. Quality \& Quantity, 49(5), 1779-1789. DOI: 10.1007/s11135-014-0054-3.

[19] HANDAL, B., L. WOOD and M. MUCHATUTA, 2011. Students' expectations of teaching: The business, accounting and economics experience. E-Journal of Business Education \& Scholarship of Teaching, 5(1), 1-17.

[20] HEINE, P. and N. MADDOX, 2009. Student perceptions of the faculty course evaluation process: An exploratory study of gender and class differences. Research in Higher Education Journal, 3, 1-10.

[21] HENDL, J., 2006. Přehled statistických metod zpracování dat. Praha: Portál. ISBN 807367-123-9.

[22] HILALI, N., S. AL-JABER and L. HUSSEIN, 2015. Students' Satisfaction and Achievement and Absorption Capacity in Higher Education, Procedia-Social and Behavioral Sciences, 177, 420-427. DOI: 10.1016/j.sbspro.2015.02.384.

[23] CHAMBERLIN, M. S. and J. S. HICKEY, 2001. Student Evaluations of Faculty Performance: The Role of Gender Expectations in Differential Evaluations. Educational Research Quarterly, 25, 3-14.

[24] CHUI, T. B., M. S. AHMAD, F. A. BASSIM and N. A. ZAIMI, 2016. Evaluation of Service Quality of Private Higher Education Using Service Improvement Matrix, 
Procedia - Social and Behavioral Sciences, 224, 132-140. DOI: 10.1016/j.sbspro.2016.05.417.

[25] KOHN, J. and L. HATFIELD, 2006. The role of gender in teaching effectiveness ratings of faculty. Academy of Educational Leadership Journal, 10(3), 121-137.

[26] KOUSHKI, P. A. and H. A. KUHN, 1982. How reliable are student evaluations of teachers? Engineering Education, 72(5), 362-367.

[27] LAUBE, H., K. MASSONI, J. SPRAGUE, A. L. FERBER, 2007. The Impact of Gender on the Evaluation of Teaching: What We Know and What We Can Do. Nwsa Journal, 19(3), 87-104. DOI: 0.1353/nwsa.2007.0057.

[28] LIU, O. L., 2012. Student Evaluation of Instruction: In the New Paradigm of Distance Education. Research in Higher Education, 53(4), 471-486. DOI: 10.1007/s11162-0119236-1.

[29] MACNELL, L., A. DRISCOLL and A. N. HUNT, 2015. What's in a name: Exposing gender bias in student ratings of teaching. Innovative Higher Education, 40(4), 291-303. DOI: $10.1007 / \mathrm{s} 10755-014-9313-4$.

[30] MARKLEY, T., 2004. Defining the effective teacher: Current arguments in education. Essays in Education, 11(3), 1-14.

[31] STOET G. and D. GEARY, 2014. Sex differences in academic achievement are not related to political, economic, or social equality. Intelligence, 48, 137-151. DOI: 10.1016/j.intell.2014.11.006.

[32] SULONG, M. S., 2014. Lecturers' perception on teaching evaluation: selection of research instruments', The Online Journal of Quality in Higher Education, 1(2), 36-44.

[33] WALUMBWA, F. O. and L. A. OJODE, 2000. Gender stereotype and instructors' leadership behavior: transformational and transactional leadership. In: Midwest Academy of Management Annual Conference, Chicago, IL, 30 March-1 April, 2000.

[34] ZARE-EE, A., Z. M. DON and I. TOHIDIAN, 2016. Gender differences in students' ratings of university teachers in the Iranian education system. Learning and Teaching in Higher Education: Gulf Perspectives, 13(1), 1-17. DOI: 10.18538/lthe.v13.n1.232. 